\title{
Asbestos-related pleural plaques: significance and associations
}

\author{
Ruwani Abeyratne, ${ }^{1}$ Peter Wills, ${ }^{2}$ Simon William Dubrey ${ }^{1}$
}

${ }^{1}$ Department of Cardiology, Hillingdon Hospital, Uxbridge, Middlesex, UK

${ }^{2}$ Department of Respiratory Medicine, Hillingdon Hospital, Uxbridge, Middlesex, UK

\section{Correspondence to}

Dr Simon William Dubrey, simon.dubrey@thh.nhs.uk
To cite: Abeyratne $R$, Wills P, Dubrey SW. BMJ Case Rep Published online: [please include Day Month Year] doi:10.1136/bcr-2013008928
A 62-year-old man presented with increasing shortness of breath. The chest $\mathrm{x}$-ray demonstrated multiple opacities (figure 1). On questioning, he had worked at a local asbestos plant, the appearances being consistent with asbestos-related pleural plaques.

One of the features of asbestos-related lung disease is the long latent period between exposure to asbestos and subsequent pathology. Asbestos-related pleural disease may present as a benign feature, including asbestos-related pleural effusions, diffuse pleural thickening or pleural plaques. The worst scenario is development of malignant pleural mesothelioma. A recent review summarises the rather difficult dilemma regarding risk. In summary, “among asbestos-exposed individuals, those having radio-

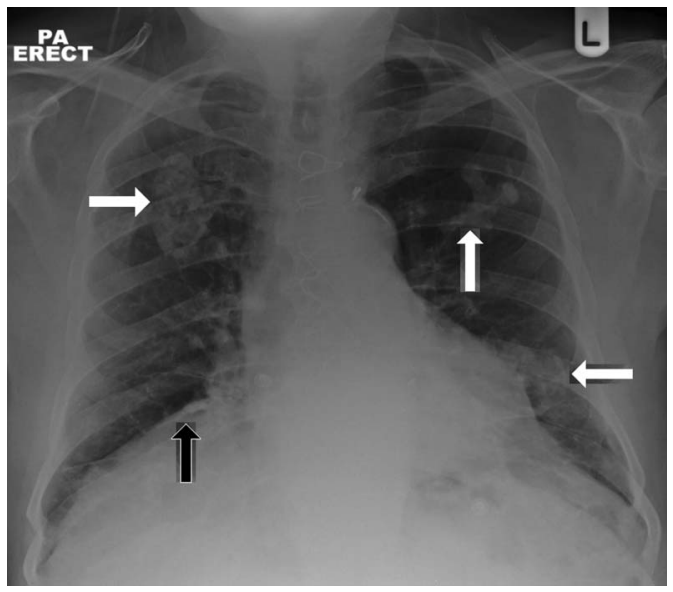

Figure 1 Chest x-ray showing bilateral pleural plaques en face (white arrows) and on the dome of the diaphragm (black arrow). graphic evidence of pleural plaques are at increased risk for lung cancer and pleural mesothelioma. However, within a population of individuals having the same cumulative asbestos exposure, there is no evidence that pleural plaques confer an increased risk of developing lung cancer or pleural mesothelioma." 1

The list of occupations associated with the use of asbestos is extensive. ${ }^{2}$ A further consideration is that family members may be exposed to 'takehome' exposure. ${ }^{3}$ An example is the washing of contaminated clothing by the partner of an asbestos-exposed worker, an association we have encountered locally. Such secondarily exposed individuals can develop pathology and should also be advised to avoid cigarette smoking, due to its recognised additive carcinogenic risk in the development of lung cancer.

A patient's present or past occupation, that of family members, geographical location and local industries can focus the diagnosis when presented with such a chest radiograph.

Contributors All authors have read and contributed to the manuscript. RA and SWD prepared the image and consented the patient.

Competing interests None.

Patient consent Obtained.

Provenance and peer review Not commissioned; externally peer reviewed.

\section{REFERENCES}

1 Ameille J, Brochard $\mathrm{P}$, Letourneux $\mathrm{M}$, et al. Asbestos-related cancer risk in patients with asbestosis or pleural plaques. Rev Mal Respir 2001;28:e11-17.

2 O'Reilly KMA, McLaughlin AM, Beckett WS, et al. Asbestos-related lung disease. Am Fam Physician 2007;75:683-8.

3 Peretz A, Van Hee VC, Kramer MR, et al. Pleural plaques related to "take-home" exposure to asbestos: an international case series. Int J Gen Med 2008;1:15-20.

Copyright 2013 BMJ Publishing Group. All rights reserved. For permission to reuse any of this content visit http://group.bmi.com/group/rights-licensing/permissions.

BMJ Case Report Fellows may re-use this article for personal use and teaching without any further permission.

Become a Fellow of BMJ Case Reports today and you can:

- Submit as many cases as you like

- Enjoy fast sympathetic peer review and rapid publication of accepted articles

- Access all the published articles

- Re-use any of the published material for personal use and teaching without further permission

For information on Institutional Fellowships contact consortiasales@bmjgroup.com

Visit casereports.bmj.com for more articles like this and to become a Fellow 